\title{
Integration in Flipped Classroom Technology Approach to Develop English Language Skills of Thai EFL Learners
}

\author{
Pongpatchara Kawinkoonlasate ${ }^{1}$ \\ ${ }^{1}$ English Department Faculty of Liberal Arts, Huachiew Chalermprakiet University, Samut Prakarn, Thailand \\ Correspondence: Pongpatchara Kawinkoonlasate, English Department Faculty of Liberal Arts, Huachiew \\ Chalermprakiet University, Samut Prakarn, Thailand.
}

Received: September 10, 2019

Accepted: October 16, 2019 Online Published: October 18, 2019

doi: $10.5539 /$ elt.v12n11p23

URL: https://doi.org/10.5539/elt.v12n11p23

\begin{abstract}
The technology of flipped classroom technology approach implies such organization of the educational process in which classroom activities and homework assignments are reversed. Nowadays, the flipped classroom technology approach is altering how we collect information, conduct research, and share data with others in the Thai educational system. New technological tools are changing the education community and how the instructors pass on knowledge to learners. With this new tool, the flipped classroom technology approach is being integrated into the classroom at larger scales in most educational levels, especially in Thailand. With more electronic resources available for instructors, new teaching methodologies are being used to improve both EFL and ESL learners. The aims of this academic paper are to acknowledge the significance of applying the flipped classroom technology approach for instructors and language skill development in learners, to discuss the process of integration into the classroom, and review possible usages with the introduction of flipped approach into the English classroom with regards to reading, writing, listening, and speaking. Throughout this paper, the term flipped classroom technology approach and integration have been defined. An explanation of the use of the flipped approach is given. Previous studies and research on the use of the flipped classroom technology approach, in order to improve English language learning skills, in the classroom have been reviewed and discussed. Positive ways this teaching methodology could be used to assist learners to improve their English language skills are also suggested.
\end{abstract}

Keywords: flipped classroom technology approach, effective technology integration, instruction, English language skills, autonomous learning, advantages

\section{Introduction of Flipped Classroom Technology Approach}

In teaching English as a global language, modern innovative teaching applications, such as the flipped classroom approach, are very popular and adopted in English courses in Thai educational institutions. Most instructors try to apply this modern teaching technique for Thai EFL learners to develop their English language skills. The flipped classroom approach in this academic paper will analyze blended learning, a combination of face-to-face in-class learning and distance learning. The flipped classroom technology approach focuses on knowledge creation according to skills, knowledge, abilities, self-learning from the experiences provided by instructors, and activities outside the classroom using a variety of information communication technology. In most modern era Thai institutions, there are a variety of teaching approaches to promote problem-solving. Therefore, the management of teaching and learning must be adapted to correspond to the new learning paradigm. To give the students the ability to manually seek security, particularly the ability to use technology in the pursuit of their knowledge (Srihirun, 2017).

The important concept of the flipped learning approach stems from constructivist learning theory that underlying of learners' role in their learning. This approach will assist them to become active learners while enhancing their engagement in classrooms Ayçiçek and Yanpar Yelken (2018). Nowadays, the flipped classroom technology approach has gained the attention of numerous researchers and educators (Basal, 2015; Ahmed, 2016; Sakulprasertsri, 2017). The study of Egbert, Herman, and Lee (2015) insist that the flipped classroom approach is very suitable for language classes because this helps foster learner autonomy through online video lessons and class activities, creates flexible learning atmosphere and adjusts learning facilities. The idea to supplement the class time with homework, assignments and readings allows the flipped classroom technology approach perfect for language instruction. The instructors are able to prepare the course before class. Therefore, the classroom 
lessons can be used as scaffolding rather than using it as traditional class's instruction.

Regarding English language learning and teaching, the flipped classroom technology approach hinges on adopting many technological techniques that allow students to be more interactive inside the class and have wider opportunities which assist EFL learners further develop their academic language proficiency and confidence." (Marshall \& DeCapua, 2013). As I have learned from my teaching experience of Thai EFL learners, advanced technology in the 21st century brings about new opportunities and challenges in their learning both inside the classroom and outside the classroom. Learners in this century have to be well-equipped with the content knowledge and all necessary skills for their lifestyles, learning, and their future careers. Pacansky-Brock (2013) insists that emerging technologies can support learning outcomes, increase learners' engagement, and prepare them to become successful learners. In this academic paper, the flipped classroom technology approach will be introduced as an alternative instructional approach. Direct instruction in-class and homework being reversed has recently received great attention from many English language instructors. The flipped classroom technology approach will be discussed in the following sections.

\subsection{The Definition of Flipped Classroom Technology Approach}

Flipped classroom technology approach is a new concept for teaching and learning which is a new medium for educators. The flipped classroom approach will be combined between e-Learning and traditional learning methods (Strayer, 2011). The key element of blended learning is the technology called "flipped classroom" which was developed by American educators Jonathan Bergmann and Aaron Sams, they define the flipped classroom as the main approach to applying technologies for learning and instruction (Bergmann \& Sams, 2012). The learners study by themselves by watching video lectures, downloading all materials from the Internet or e-Learning programs. Classroom activities include practicing and discussing with the instructor about the major themes. According to Jungić, Kaur, Mulholland and Xin (2015), the flipped classroom approach means the instruction where students learn new contents through electronic resources during out-of-class time. At the same time, AlJaser (2017) defined the flipped classroom as a student-centered educational learning model that "aims at replacing the traditional lecture by active cooperative tasks using internet and computer technology to transmit a video lecture to be watched at home; and then students discuss it through some pair activities" (p. 69). According to the above definition, the flipped classroom technology implies such organization of the educational process in which, when students attend face-to-face classes, they already have some theoretical knowledge and understanding of the matter that will be discussed in the classroom.

In Thai educational institutions, many educators and instructors are more interested in the flipped classroom technology approach to master and apply in teaching and learning processes (Thaichay, 2014). Moreover, learners are involved in practical activities in the classroom. They also work in the e-learning environment individually or in groups watching video lectures, checking their knowledge by answering comprehension questions or studying additional learning resources. In class, they expand the material studied mainly by solving practical tasks, making projects and discussing various important issues on the topic. After classroom activities, they are working with electronic courses where they are engaged in testing their knowledge of the subject and evaluating their peers' work (Farrah \& Qawasmeh, 2018). Furthermore, in Thailand, the study of Sakulprasertsri and Vibulphol (2016) insist that using flipped learning approach in the English language classroom enhances learners' English ability, and the level of learners' motivation in English learning is higher resulted from experiencing learning in flipped learning approach.

In the flipped classroom technology approach, the instructors will not only teach and prepare all learning materials, but they also facilitate their professional learning and development, link the flipped learning approach with suitable practices, introduce innovations to the classroom, and conduct research to help improve their students. To begin with this modern chance, the flipped classroom technology approach offers more time for learners during the teaching procedures to practice English language through various learning tasks and activities such as role plays, simulations, games, discussion, and presentation (Doman \& Webb, 2017). According to flipped learning educators and researchers (Sakulprasertsri \& Vibulphol, 2016; Lee \& Wallace, 2017; Doman \& Webb, 2017), the flipped learning approach also develops information media and technology skills for learners as one of the required skills in the $21^{\text {st }}$ century, and there are several suggestions on how to implement the flipped learning approach in English classroom.

Consequently, technology in the flipped classroom is one of modern innovations that allows learners to maximize their participation, increase their motivation, and improve their English language skills. In my teaching experience with Thai EFL learners, applying technological devices during the instruction is very beneficial for learners. The learners can search for all information related to their studies both inside and outside 
the classroom, and they can practice their lessons as much as they want. Consequently, the learners' involvement and ability to improve their language performance in the classroom is based on the instructors' approach.

\subsection{The Format of Flipped Classroom Technology Approach}

Flipped classroom technology approach in this academic paper means a key pedagogical innovation that displays potential in reaching countless diverse learners in the classroom. Applying technology and engaging tasks that offer varied cognitive challenges for learners can help develop their higher-order thinking skills and encourage life-long learning. In a flipped classroom, all learners have to prepare their lessons, read, or watch lecture videos before they come to class (Kurt, 2018). When the class begins, all learners spend time in the classroom discussing, problem-solving or participating in other kinds of active learning that can assist them to actualize and assimilate their new knowledge. Learners must review their study before the class meets because it motivates the learners with self-directed learning. During my time using the flipped classroom approach, the learners are motivated to review and study their lessons before coming to the class. When the class begins, the learners discuss the point in each lesson in class, and they share their ideas with their partners. They gain more new knowledge on their own beyond class time, and during the class, the learners receive benefits like scaffolding support from their instructors. The figure below is a sample framework for using the flipped classroom technology approach.

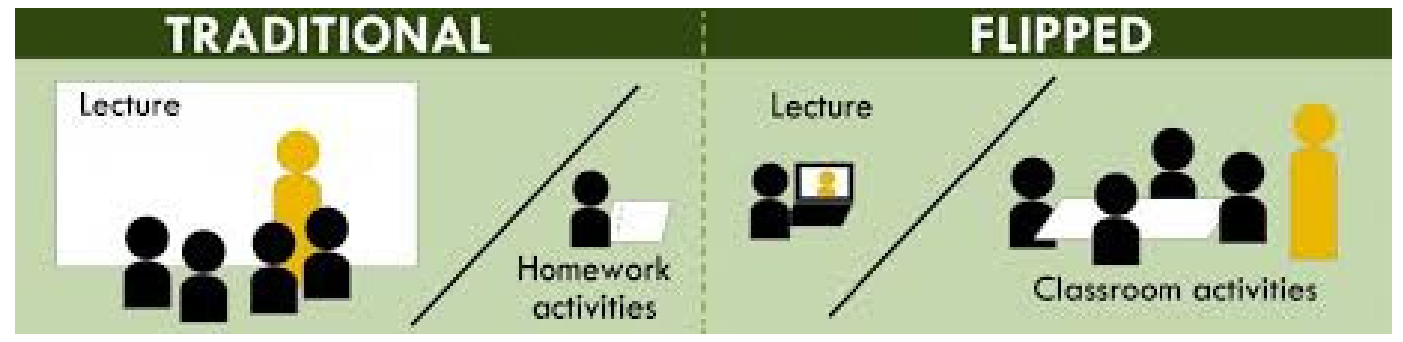

Figure 1. Flipped classroom technology approach (Kurt, 2018)

Normally, the underlying concept of the flipped classroom technology approach comes from constructivist learning theory that emphasizes learners' role in learning by assisting them to become active learners while enhancing their engagement in the classroom (Sakulprasertsri, 2017). The instructional materials that contain content of one particular unit will be introduced and viewed by the learners at home before the class meets. However, homework, exercises, projects or class discussions are done in class time. Videos are developed and created by the instructors and posted online or selected from online resources which are the main applications in the flipped classroom. Below are the three stages which I used during my time teaching Thai EFL learners in the flipped classroom technology approach.

Stage 1: Pre-class time, the learners prepare the lessons by themselves. They can study from an online course or video from the Internet which is provided by the instructors. When they finish, they produce some exercises to check difficult points in the lesson before coming to the class. This stage provides the learners' background knowledge relevant to their topic.

Stage 2: During-class time, all learners become the main participants of the teaching contents and interact effectively with their instructors as well as classmates. Instead of being passive knowledge receivers, they become the center of the class and are entitled to decide learning time, place and contents. In this stage, the class becomes student-centered. The learners share and discuss all the information that they have collected before class. They should have a deep understanding of the contents. Moreover, they try to find the answers to their problems through discussions. The teachers' role during this stage is the facilitator.

Stage 3: After the lesson, providing feedback is conducive to assist the learners to learn about the problems which exist in the flipped classroom. The goal is to let their peers accurately grasp the students' problems during the lesson. In this stage, the instructor explains and communicates with the learners after class to assert that they understand what they have learned and the teaching objectives.

Using the flipped classroom technology approach, learners must have the ability to self- regulate their learning which allows the learners to become the main structure of learning. Student-centered and self-directed learning is an important factor for learners. The application of a flipped classroom technology approach increases the learners' interest and motivation in their learning. It makes full use of the classroom time and resources as well 
as improves the classroom teaching efficiency. Furthermore, the flipped classroom approach will change the traditional teaching method because it makes students the center of the lesson, which emphasizes learners' self-directed study.

\subsection{Effective Tools of Flipped Classroom Technology Approach}

With the growth of new fast and powerful technology, the flipped classroom technology approach is a modern application which can provide both ESL/EFL teachers and learners with virtually boundless uses. It promotes both online learning and traditional teaching methods. The flipped classroom model depends basically on using some functioning digital technologies and tools like videos, presentations, and websites (Abdelshaheed, 2017). Flipped lessons replace teacher lectures with instructional material. A video is one tool for students to watch and interact with at home. However, there are a variety of digital technologies and tools such as videos, presentations, and websites. The teacher and administration possess many options in technology that can be both good and bad for their use in the flipped classroom. Most of the researchers suggest videos as a tool to use in the flipped classroom such as (DeGrazia, Falconer, Nicodemus, \& Medlin, 2012; Enfield, 2013; Pearson Education, 2013; Sung, 2015) also suggest that with video lectures outside the classroom, students come to class more prepared. Based on the classes I have experienced, I would like to share the effective tools which I have used in the flipped classroom to develop Thai EFL learners' English language instruction.

1). e-Learning, since the early 2000s, blended learning (BL) a convergence of traditional teaching methods with technology-mediated online learning has emerged in the Thai educational system. e-Learning is intended to offer a more interactive and flexible learning environment for students that fosters core values of higher education such as advanced research and scholarship programs or critical and creative knowledge claims (Lee \& Jang, 2014). For designing the course, e-Learning is used for teaching and learning purposes in which instructors use this system to share notes and current information regarding the subjects with their learners. All course materials are designed and uploaded in the e-Learning platform. The learners can study and search for more information which allows learning to be more interesting with the integration of technology in English language learning. There are many alternatives which can suit different learning styles, so the application of interesting approaches in e-Learning may also initiate the students' interest in learning the language.

2). YouTube is one modern tool that I have used to teach English. Using YouTube videos to teach English classes as supplementary material provides learners with a good understanding and knowledge of their lectures. Also, it is likely to make the learning process more fun and meaningful. According to Abdulrahman Almurashi (2016), YouTube is considered a source of online material that could play a crucial role in the instructional field. It has become more popular with people of all ages, especially among adults because this website can provide learners with everyday videos and authentic situations that will assist them to improve their understanding and performance in English language learning. Another study by Seilstad (2012) also insists that using YouTube clips as a new method for teaching English is beneficial for designing the courses. Hence, YouTube could be useful to incorporate into English lessons and an effective method in dealing with learners' difficulties and barriers.

3). Dropbox is a free, education-specific tool that allows educators to create a unique online workspace with their students. Dropbox essentially removes the need for students to print out assignments and send large attachments. Each account can save up to $2 \mathrm{~GB}$ of data with a free trial. Students can share links or invite others to review and make changes to documents in a particular file. This free tool can allow learners to monitor their progress and view past lessons. In my class, using Dropbox is the simplest tool for learners to upload their work to a shared space. Dropbox allows all learners to store, access, download and share resources anywhere. Therefore, instructors can enact the flipped classroom approach by using this tool.

4). Google Classroom makes it easy for instructors to keep all of their instructional materials in one place. Instructors are able to combine the advantages of flipped classrooms with the advantages of differentiated instruction. Using Google Classroom in the flipped classroom allows learners to integrate materials from Docs, Sheets, Drive, and Gmail. Therefore, it is easy for instructors to make assignments for learners who can then access the instructional materials that they need, and for teachers to assess the learners.

The tools listed above all help instructors facilitate a flipped classroom. The technology allows learners more time to apply knowledge and instructors more time for hands-on education. With the help of these tools, instructors can implement a flipped classroom technology approach with learners working on their own either at home or in the classroom and provide a more individualized learning experience for all learners. The four tools above are better tools for instructors to use in the flipped classroom. 


\section{How to Integrate the Flipped Classroom Technology Approach for Teaching English Language Skills}

In Thai English language instructional systems, many scholars have implemented the flipped classroom model to measure its effect. Based on the research studies, applying flipped classroom technology approach develops learners' English language skills including reading, writing, listening, speaking, and grammar as well (Kuo, Hsu, Fang, \& Chen, 2014; Song, 2015; Ahmed, 2016; Chen, Hsieh, Wu, \& Marek, 2016). In the flipped classroom, the instructors should provide classroom activities to promote the learning process, such as games, role-plays and small group discussions. In my experience, EFL learners enhanced their English language skills when I applied this approach in the classroom. The learners had a positive attitude with this teaching methodology more than a traditional teaching method. I used the flipped classroom technology approach in many courses such as reading courses, writing courses, speaking courses, and grammatical structure courses. The learners were satisfied with these courses, and they were willing to study and practice their lessons by themselves before each class.

Ahmed (2016) insists that using a flipped classroom technology approach develops learners' writing skills in English as a Foreign Language and learners' attitude towards flipping the classroom positively. Similarly, the study of Chen Hsieh, Wu and Marek (2016) showed that using the flipped classroom approach enhanced EFL learning. Computer Assisted Language Learning points out that using the flipped classroom approach can enhance EFL learning. Moreover, they found that the theory-based flipped instruction using online written and oral interaction not only enhanced the participants' motivation, making them more active in class, but also the flipped learning was successful in achieving the instructional goals of the class. Additionally, Sung (2015) indicates that the flipped teaching approach is a good momentum for change in current ELT. This can be seen in most research studies which include using the flipped classroom technology approach to improve language learning.

To compare the flipped learning approach and other approaches to English classrooms especially in Thailand is another issue to be discussed. There are variety of teaching methodologies for the instructors to use while they are lecturing. The traditional teaching method or face to face class learning, task-based learning, problem-based learning, communicative language teaching, and so on allow learners to learn and practice the target language through interaction with one another and the instructor (Sakulprasertsri, 2017). Nevertheless, these approaches view learner-centered classroom as the rule rather than exception and rely on the functional-notational syllabus which places heavy demands on the learners. However, the flipped learning approach allows for a great amount of engagement with authentic materials outside of the classroom since it provides learners more opportunities to learn whenever and wherever and emphasizes the interaction between learners through completing tasks and projects including communicative and collaborative tasks. The advantages of flipped classroom technology approach are; learners can access lecture videos whenever and wherever they want. It provides students to learn at their own speed. The learners that are educated with this approach are encouraged to think both within and out of class, and this model includes both active learning and the advantages of individual learning (Bishop \& Verleger, 2013).

From my instructional experience, the effects of change reflect the extent of the new teaching strategies. Applying the flipped classroom technology approach in my teaching was very interesting for me and my learners. This approach is a modern teaching methodology for Thai EFL learners. For example, I designed my essay writing course with e-Learning and e-Writing programs, and I identified the content that students would learn outside of the classroom in order to invest more time in the classroom for applying what was prepared by the students. That is, students could actively learn information about new lessons at any time outside the classroom by using smartphones or computers. These technology tools enable learners to playback an educational program or lessons several times to understand the new information.

In this implementation of the flipped classroom technology approach, the individual leaner's learning performance can be improved, and the learners' enjoyment and motivation can be increased instead of boredom during their learning. The learners can practice their English writing ability many times as much as they want. They have a chance to share their knowledge with their classmates when the class meets. In a nutshell, integrating the flipped classroom model can be useful for learners to master their studies, provide learners with an exciting educational environment, improve the role of the lecturer to become a facilitator and the learners become autonomous learners, and enhance the learners' critical thinking, self- learning, and experience building.

\section{Learning Achievements Through Flipped Classroom Technology Approach}

With globalization, advanced technological applications bring about new opportunities and challenges in all aspects, especially in education. Different teaching methodologies and styles of learning have taken place over the years. It could be that there is no best approach to apply in a classroom, but there are approaches that work 
better both for the instructors and the learners. It is the educators' responsibility to makes sure their learners are understanding what they are being taught. Instructors need to prepare their students to become $21^{\text {st }}$-century learners, which means the students need to know how to use a variety of technologies effectively (Zupon, 2017). There are many different teaching methodologies and strategies for instructors to use in their classroom. Zupon (2017) insists that the flipped classroom technology approach has become a strategy used by the instructor. One that has the potential to be effective with learners. There are many educators that have proven that applying the flipped classroom technology approach may be one of the better approaches to lead the learners' achievement. The flipped learning approach can be employed in English classrooms to enhance learners' engagement and other skills needed (Bergmann \& Sams, 2012; Balan, Clark, \& Restall, 2015; Sakulprasertsri, 2017; Elian, 2018).

Providing learners with adequate technology tools, modern laboratory devices, and high-speed internet to help instructors prepare the needed materials according to the flipped classroom strategy. The instructors can choose the best use of technology in the classroom by developing their awareness of a range of digital technologies and considering carefully both how and why they can be used to support students' learning. Effective selection of software and devices are a part of the instructor's decision to make learning successful. To begin with modern technology, the flipped learning approach provides more time for learners during the teaching procedures to practice the English language through various learning tasks and activities. Introducing the flipped classroom technology approach in teaching to English language classrooms, especially in Thailand and other countries where English is a second or foreign language can enhance the learner's experience and achieve proficiency by themselves. The following section aims to review the studies that have been conducted using the flipped classroom technology approach.

According to AlJaser (2017), the effectiveness of using flipped classroom strategy in academic achievement and self-efficacy of college students is a productive tool that makes learning, teaching, and lecturing more exciting and interesting. Meanwhile, a study of Sirakaya and Ozdemir (2018) reveals that using flipped classroom approach in English language learning improves the learners' achievement better, promote more autonomous learners and creativity, and increase the learners' academic performance. Furthermore, Villanueva (2016) insists that using a flipped classroom technology approach motivates the individual need of the learners. The flipped classroom technology allows learners to have more efficient management for the time in the classroom and better achievement in learning and provides them with more opportunities to communicate with their classmate and instructor (Unakorn \& Klongkratoke, 2015). Similarly, the study of Basal (2015), flipped classroom technology approach encourages collaboration among learners, overcomes the limitation of their study in the classroom, and increase the learners' participation.

From the aforementioned studies, the flipped classroom technology approach helps learners to improve academic achievement, autonomous learning, communication skills, and collaborative learning. The flipped classroom approach facilitates class discussion in an enjoyable way and provides a way for the instructor to check if learners are clear, and they understand the concepts that they have been taught. This academic paper, the author suggests for instructors to combine this teaching approach not only in English instruction but also in other courses such as Science, Math, Social Study, and so forth. It might be better for learners in this century to use new evolving technology in the educational system, especially for English as Foreign Language learners.

\section{Autonomous Learning in Flipped Classroom Technology Approach}

Enhancing autonomy use of technology for language learning is one of the more important factors for maximizing the potential of technology for language learning. Autonomy is worth investigating as a great tool to motivate learners. One of the main goals for instructors is to assist learners to become autonomous so that they will be able to facilitate their own learning. For English as a foreign language (EFL) learners, autonomous language learning could implicate engaging in everyday activities and classes. Bravo, Intriago, and Holguin (2017) claim that autonomous learning is an important element to learn the target language. However, Dörnyei and Ushioda (2013) also believe that EFL learning success is related to learners' motivation, and motivation, autonomy and learning achievement of learners are interrelated forming a cyclical process. Furthermore, the relevance of autonomy to motivation, some researchers consider that motivation reinforces autonomy (Najeeb, 2013; M. C. Cheng \& T. P. Cheng, 2013; Dörnyei \& Ushioda, 2013). Language motivation and learner autonomy go together and also autonomous language learners are by definition motivated learners.

In this paper, applying the flipped classroom technology approach changes in how students learn. The use of the flipped classroom technology approach is one of the teaching methods that the instructors can use to bring more technology into the students' learning environment and support autonomous learning. The study of Sanprasert (2010) points out that autonomous learning is acquired and fostered through formal education, and language 
instructors will support their learners' autonomy through appropriate training that promotes learners' tasks personally. The learners express their point of view freely in terms of the learning environments and time, similarly find chances to choose activities, participate in decisions, express themselves more, and experience leadership skills. Due to these facts, the learners will become student-centered and feel more self-confident. During my teaching experience using a flipped classroom, the learners expressed a positive attitude toward the modern teaching technology approach in terms of freedom, flexibility, enthusiasm, and autonomy.

To lead with this teaching approach, educational institutions and language learning centers should combine the use of modern technological approaches into the learning curriculum to provide learners with the means of developing and enhancing their autonomous learning. In the learning process for Thai EFL learners, teaching media is an important factor to consider when instructors design the course. According to the aforementioned studies, it can be concluded that motivation, autonomous learning, and the flipped classroom technology approach play a crucial role in organizing instruction. If the learners study with the thing that they are interested in, they will be motivated and study autonomously. Their learning achievement or skill has been shown at a high level.

\section{Suggestions for the Effective Integration of Flipped Classroom Technology Approach}

At present, the importance of technological appliances in the teaching and learning process of English language skills (reading, writing, listening, speaking, and grammatical structures) is considered the technology integration process for English language teaching and learning. The concept of technology integration is the effective use of technology in the education system and the benefit of technology in the teaching and learning process. It is necessary to use common hardware and software tools to effectively integrate the flipped classroom approach. Instructors have to know the socio-cultural structures of the learners, their qualifications, economic levels, technology ownership, and learners' attitudes and beliefs about technology. The most important thing to use effective integration of the flipped classroom technology approach is the selection appropriate method and course.

As instructional technological appliances, these can facilitate learning in several ways. Two specific areas in which technology could be more valuable are presenting content and assessing achievement of the learners. The suggestions below are a guideline for the instructors who are willing to change their teaching style from the traditional teaching method to technological learning style. The effective integration of flipped classroom technology approach into English language skills including grammar is presented as the following.

1). Reading is one of the most challenging skills in learning English as a Foreign Language. Reading comprehension is a crucial factor for all languages as language learners have to become skilled in reading to gain knowledge of the language (Eng, Mohamed, \& Ismail, 2016). The study of Sung (2015) suggests using online activities on Learning Management System flat form to preview lesson materials such as reading passages and videos in his class. In addition, McDermott \& Gormley (2016) offer to use technology in teaching an interactive program through assorted activities, sharing some reading texts, and focusing on both the interactive and independent learning of learners in the reading class. In my teaching class, the author recommends using the e-Learning program to design supplementary reading materials. In the program, there are 12 reading passages with exercises for learners to study before coming to class with production exercises provided. There are various methods to design the courses with the flipped classroom technology for learners which create a good learning environment and encourage the learners' and become successful English language users.

2). Writing is more difficult than other language skills. Therefore, the instructors should design the teaching style to match with the learners' needs. Writing is a challenging and difficult process as it includes multiple skills such as identification of the thesis statement, writing supporting details, reviewing, and editing. In addition, the writers should pay attention to sentence structures, spelling, punctuations, mechanics, organizations, and concept of ideas. To overcome the difficulties of writing, the author suggests the flipped classroom technology by designing the writing course using an e-Writing program. E-Writing is designed by google form. The learners are able to study the writing strategies before they start writing to make sure that they understand the lesson. In the program, the learners can practice their writing as much as they want. They can start from prewriting, drafting, revision, and writing a final copy. Moreover, Bretzmann (2013) suggests videos, pods, books, website, or blogs through flipped teaching at home for learners to study by themselves. Similarly, Ahmed (2016) claims that the learners can search a variety of learning resources online, watch English videos on YouTube, and practice some quizzes posted on the Facebook page to develop their writing skills in English.

3). Listening is one of the most important skills in English language learning for EFL learners. Improving listening skills can have an enormous impact on the learners' ability to speak a new language. The instructors can use many kinds of technology-based materials such as video recordings, narrated presentations, podcasts, course 
notes, and Youtube. The instructors design and create contents via video which can be viewed by the learners at home. Interaction amongst themselves and the instructors should be carried out in the classroom discussions. According to O'Flaherty and Philips (2015), the prior class preparation and instructional videos provided opportunities for students to master conversational strategies, vocabulary, pronunciation, and other communication skills to better perform in classroom activities. In my opinion, this is a better teaching and learning model for learners' preparation. They can respond to the tasks more effectively. In addition, the learners perceived their motivation, effectiveness, engagement, flexibility and overall satisfaction towards this model rather positively. It completely validates the use of the flipped classroom instruction as it individualizes the pace of learning.

4). Speaking is involved in the use of the target language to effectively communicate ideas orally. To develop speaking abilities, the instructors in the digital era should combine electronic resources and information for learners to preview subject contents before the class meets which follows the student-centered approach and motivated learning method. In my experience, applying the flipped classroom technology approach using lecture recording, Youtube, and Facebook is effective for my students. The learners enjoy practicing their speaking at home and producing exercises before coming to class. Practicing every day assists the learners to develop their English speaking. In my perspective, using the flipped classroom technology approach provides opportunities for learners to gain exposure to input before class, and prepare themselves before discussion in the classroom. The study of Quyen and Van Loi (2018) insists that integrating the flipped classroom approach will help the learners develop their speaking skill. The results of their study reveal that learners improve their speaking skills while they are studying through the flipped model, and they had a positive perception of the lesson. The flipped classroom technology approach creates a learning environment that promotes better learning opportunities, especially for EFL learners.

5). Grammar is an important part of English language instruction. In the influence of the curriculum reform environment, English language instruction has been emphasized on the usage of grammatical structures. In my perspective, the flipped classroom technology approach brings a new horizon to the field of grammar instruction for Thai EFL learners. For grammatical instruction, the course is designed and integrated by the e-Learning program and Youtube video clips. All contents and exercises are uploaded on the program. Video clips and social media play an important role in a flipped classroom since most lessons are carried out via videos and other media. This provides the learners with all kinds of activities to master the knowledge in class, which may help arouse students' learning interests and achieve learning outcomes. Furthermore, it allows for more collaboration and discussion to construct learning together. The study of Jeoffrey Pudin (2017) reveals that applying flipped classroom technology could create rich and meaningful learning activities, and the learners' English grammar will be improved. Meanwhile, LI, Hai-Ming, Dong-Ge, and Xiao-Juan (2017) have a similar result in that the flipped classroom approach increased the learners' interest in grammar learning. It takes full use of the classroom time and resources as well as improves the classroom teaching efficiency. Flipped classroom enriches the content and method of grammar learning, and improving learners' self-directed learning.

In an innovative teaching practice mode, a flipped classroom technology approach is a kind of teaching methodology that enables learners to be at the center of the lesson, which stimulates learners' autonomous learning. In my point of view, the flipped classroom technology approach should be used in other subjects. This is recommended as integration with learning activities in social media and the learning activities in the classroom so that the learners can study by themselves and prepare the lessons before the class meeting.

\section{Advantages of Flipped Classroom Technology Approach for Thai EFL Learners}

In teaching English as a global language, the integration of the flipped classroom into the educational process leads to an increase in learners' motivation and interest in studying foreign languages. Furthermore, it has a positive impact on learners' self-discipline and self-directedness because students take on responsibility for their learning. The flipped classroom technology approach has a huge pedagogical potential for both teachers and learners. Developing learners' knowledge and skills pertinent to computer technology provides an important opportunity, regardless of the learners' background. Technology assists learners in adjusting their learning process, and they can have access to a lot of information that their instructors are not able to provide (Pourhossein Gilakjani, 2017). Furthermore, the application of technologies has great potential to change existing language teaching methods.

In my opinion, learners' cooperation can be increased through technology. Cooperative learning is an important factor for instruction. Learners cooperatively working together will create tasks and allow them to learn from each other through their peers' work. The study of Parvin and Salam (2015) insists that using technology allows 
learners to have a chance to increase their exposure to language in a meaningful context and make promote their knowledge in the desired language. Learners should have opportunities for social interactions to practice real-life skills. This is achieved through learners' cooperation in real activities.

Applying the flipped classroom technology approach will be very useful for learners to develop their learning process. Many studies support the flipped classroom in language learning as it provides positive ideas, benefits that motivate learners to become autonomous learners, offers collaborative work, and creates more interesting learning environments (Al-Zahrani, 2015; Ahmed, 2016; Basal, 2015; Jeoffrey Pudin, 2017; Zheng, Chu, Wu, \& Gou, 2018). Consequently, the flipped classroom technology approach is in line with constructivist and student-centered approaches to learning. There is a need to encourage the students to become student-centered learning that meets learners' interests and motivate them to take responsibility for their learning.

Moreover, the author suggests that instructors should apply the flipped classroom technology approach for all courses and incorporate technology into their teaching to achieve better learning outcomes, and also include technology in their classroom to create better learning opportunities for their learners. This teaching methodology gives instructors the chance to interact more meaningfully with their learners, meet their specific needs, and provide their learning achievement. This teaching approach can be a reliable way for instructors to make good use of classroom time, foster critical thinking, self- directed learning, building experiences, communication skills, and cooperation among the leaners. This could be seen as a modern technological solution which can treat the academic weaknesses of some learners and ensure the development of their thinking's skills.

However, the flipped classroom technology approach is a new pedagogical model which has emerged frequently nowadays in educational system. In this approach, low level skill' knowledge acquisition' is allocated to the learners. Flipped classroom technology approach has disadvantages just as many pedagogic methods. Rivera (2015) claimed that both instructors and learners might encounter with some problems. The learners are not able to interact during they are watching video, and the instructor may be suspicious about whether the learners acquired the new knowledge during the video sessions because of insufficient feedback. For the instructors, it requires a thorough preparation of materials and dynamics, which implies more workload for them to prepare the course (McCarthy, 2016). If the learners miss a step or can't follow the exercise, they have to wait until class to resolve the issue (Strayer, 2012). A study of Ferreri and O'Connor (2013) claim that the learners expressed negative attitudes toward the use of flipped classroom despite the fact that they improved their learning and communication skills. In spite of many supports from numerous studies as mentioned above, a few studies show the opposite results. These are some little problems of using the flipped classroom technology approach.

Therefore, applying the flipped learning approach in education has many technological benefits in today's instruction. This modern technological approach is considered one of the active practices that enable the learners to link between what they have learned and their personal life's experiences. The learners will have a great opportunity to reflect on the material and complete their analysis without the pressure of a traditional teaching methodology. The learners can retain information more and more because it empowers them to think critically and truly absorb the information. Applying the flipped classroom technology approach will become a driving force in both English as Foreign Language and English as a Second Language learners to achieve their academic levels.

\section{Summary}

Flipped classroom technology approach is a teaching methodology that leads to an increase in learners' participation, motivation, critical thinking, communication skills, and interest in studying foreign languages. The flipped learning approach in this academic paper is a pedagogical model which reverses classroom activities. The materials, contents, and supplementary tools are provided online and learners can study the lesson objectives prior to coming to class. More classroom time could be used to engage in activities such as problem-solving, discussion and analysis. The flipped classroom technology approach is also a key pedagogical innovation that displays potential in reaching countless diverse learners in the classroom. Applying a flipped classroom technology approach is likely to present additional valuable outcomes in the process of learning and learning environments. It has a huge pedagogical potential for both instructors and learners. The use of technology and traditional methods can be an alternative for future English courses since it is an invaluable learning experience for learners. Therefore, educators and instructors should incorporate technology into their teaching to achieve better learning outcomes and also include technology in their classroom to create better learning opportunities for their learners.

\section{References}

Abdulrahman Almurashi, W. (2016). The effective use of YouTube videos for teaching the English language in 
the classroom as supplementary material at Taibah University in Alula. International Journal of English Language and Linguistics Research, 4(3), 32-47. https://doi.org/10.5296/jsel.v4i1.9423

Abdelshaheed, B. S. M. (2017). Using a Flipped Learning Model in teaching the English language among female English majors at Majmaah University. English Language Teaching, Canadian Center of Science and Education, 10(11), 96-110. https://doi.org/10.5539/elt.v10n11p96

Ahmed, M. A. E. A. S. (2016). The effect of a flipping classroom on writing skill in English as a foreign language and students' attitude towards flipping. US-China Foreign Language, 14(2), 98-114. https://doi.org/10.17265/1539-8080/2016.02.003

Al-Zahrani, A. (2015). From passive to active: The impact of the flipped classroom through social learning platforms on higher education students' creative thinking. British Journal of Educational Technology, 46(6), 1133-1148. https://doi.org/10.1111/bjet.12353

AlJaser, A. (2017). Effectiveness of using flipped classroom strategy in academic achievement and self-efficacy among education students of Princess Nourah Bint Abdulrahman University. Canadian Center of Science and Education, 10(14), 67-77. https://doi.org/10.5539/elt.v10n4p67

Ayçiçek, B., \& Yanpar Yelken, T. (2018). The Effect of Flipped Classroom Model on Students' Classroom Engagement in Teaching English. International Journal of Instruction, 11(2), 385-398. https://doi.org/10.12973/iji.2018.11226a

Balan, P., Clark, M., \& Restall, G. (2015). Preparing students for flipped or team-based learning methods. Education \& Training, 57(6), 639-657. https://doi.org/10.1108/ET-07-2014-0088

Basal, A. (2015). The implementation of a flipped classroom in foreign language teaching. Turkish Online Journal of Education- TOJCE, 16(4), 28-37. https://doi.org/10.17718/tojde.72185

Bergmann, J., \& Sams, A. (2012). Flip Your Classroom: Reach Every Student in Every Class Every Day. Arlington: ISTE.

Bishop, J. L., \& Verleger, M. A. (2013). The flipped classroom: A survey of the research. In ASEE National Conference Proceedings, Atlanta, GA.

Bretzmann, J. (2013). Flipping 2.0: Practical strategies for flipping your class. NerBerlin, WI: The Bretzmann Group LLC.

Bravo, J. C., Intriago, E. A., \& Holguin, J. V. (2017). Motivation and autonomy in learning English as a foreign language: a case study of Ecuadorian college students. English Language Teaching, 10(2), 100-113. https://doi.org/10.5539/elt.v10n2p100

Cheng, M. C., \& Cheng, T. P. (2013). Reflections on the Role of Motivation on Learning English for Successful College EFL Learners in Taiwan. World Journal of Education, 2(5), 8-14. https://doi.org/10.5430/ wje.v2n $5 \mathrm{p} 8$

Chen Hsieh, J. S., Wu, W. C. V. \& Marek, M. W. (2016). Using the flipped classroom to enhance EFL learning. Computer Assisted Language Learning, 30(1-2), 1-21.

DeGrazia, J. L., Falconer, J. L., Nicodemus, G., \& Medlin, W. (2012). Incorporating Paper presented at the 119th Annual Conference of the American Society for Engineering Education, San Antonio, TX. Retrieved from http://www.engr.uky.edu/ aseeched/papers/2012/5025.pdf

Dörnyei, Z., \& Ushioda, E. (2013). Teaching and researching: Motivation. Routledge.

Doman, E., \& Webb, M. (2017). The Flipped Experience for Chinese University Students Studying English as a Foreign Language. TESOL Journal, 8(1), 102-141. https://doi.org/10.1002/tesj.264

Egbert, J., Herman, D., \& Lee, H. (2015). Flipped instruction in English language teacher education: A design-based study in a complex, open-ended learning environment. Teaching English as a Second or Foreign Language, 19(2).

Eng, L., Mohamed, A., \& Ismail, S. (2016). Systematic Tracking of Malaysian Primary School Students' ESL Reading Comprehension Performance to Facilitate Instructional Processes. INT J INSTRUCTION, 9(1), 149-162. https://doi.org/10.12973/iji.2016.9112a

Elian, S.A. (2018). The effect of using a flipped classroom strategy on the academic achievement of fourth-grade students in Jordan. International Journal of Emerging Technologies in Learning, 13(2), 110-125. https://doi.org/10.3991/ijet.v13i02.7816 
Enfield, J. (2013). Looking at the impact of the flipped classroom model of instruction on undergraduate multimedia students at CSUN. Tech Trends, 57(6), 14-27. https://doi.org/10.1007/s11528-013-0698-1

Farrah, M., \& Qawasmeh, A. (2018). English students' attitudes towards using flipped classrooms in language learning at Hebron University. Research in English Language Pedagogy. RELP, 6(2), 275-294.

Ferreri, S. P., \& O'Connor, S. K. (2013). Redesign of a large lecture course into a smallgroup learning course. American Journal of Pharmaceutical Education, 77(1), 122-142. https://doi.org/10.5688/ajpe77113

Jeoffrey Pudin, C.S. (2017). Exploring a flipped learning approach to teaching grammar for ESL students. Indonesian Journal of English Language Teaching and Applied Linguistics, 2(1), 51-64. https://doi.org/10.21093/ijeltal.v2i1.47

Jungić, V., Kaur, H., Mulholland, J. \& Xin, C. (2015). On flipping the classroom in large first-year calculus courses. International Journal of Mathematical Education in Science and Technology, 46(4), 508-520. https://doi.org/10.1080/0020739X.2014.990529

Kuo, F. R., Hsu, C. C., Fang, W. C., \& Chen, N. S. (2014). The effects of Embodiment-based TPR approach on student English vocabulary learning achievement, retention, and acceptance. Journal of King Saud University - Computer and Information Sciences, 26(1), 63-70. https://doi.org/10.1016/j.jksuci.2013.10.003

Kurt, S. (2018). Flipped Classroom. Retrieved from https://educationaltechnology.net/flipped-classroom

Lee, J., \& Jang, S. (2014). A methodological framework for instructional design model development: critical dimensions and synthesized procedures. Educational Technology Research and Development, 62(6), 743-765. https://doi.org/10.1007/s11423-014-9352-7

Lee, G., \& Wallace, A. (2017). Flipped learning in the English as a foreign language classroom: Outcomes and perceptions. TESOL Quarterly, 1-23. https://doi.org/10.1002/tesq.372

Li, Z., Hai-Ming, W., Dong-Ge, W., \& Xiao-Juan, J. (2017). Application of flipped classroom in grammar teaching. Advances in Social Science, Education and Humanities Research, 90, 254-260. https://doi.org/10.2991/sschd-17.2017.51

McCarthy, J. (2016). Reflections on a flipped classroom in first year higher education. Issues in Educational Research, 26(2), 332-350.

McDermott, P., \& Gormley, K. (2016). Teachers' use of technology in elementary reading lessons. Reading Psychology, 37(1), 121-146. https://doi.org/10.1080/02702711.2015.1009592

Marshall, H., \& DeCapua, A. (2013). Making the transition to classroom success: Culturally responsive teaching for struggling language learners. University of Michigan Press. https://doi.org/10.3998/mpub.4625213 McLaughlin

Najeeb, S. S. R. (2013). Learner autonomy in language learning. Procedia - Soc. Behav. Sci., Akdeniz Language Studies Conference, May 2012, Turkey 70, 1238-1242. https://doi.org/10.1016/j.sbspro.2013.01.183

O'Flaherty, J., \& Philips, C. (2015). The use of flipped classrooms in higher education: A scoping review. Internet and Higher Education, 25, 85-95. https://doi.org/10.1016/j.iheduc.2015.02.002

Pacansky-Brock, M. (2013). Best practices for teaching with emerging technologies. New York, NY: Routledge. https://doi.org/10.4324/9780203095966

Parvin, R. H., \& Salam, S. F. (2015). The effectiveness of using technology in English language classrooms in government primary schools in Bangladesh. FIRE: Forum for International Research in Education, 2(1), 47-59. https://doi.org/10.18275/fire201502011049

Pearson Education, Inc.. (2013). Flipped learning model dramatically improves the pass rate for at-risk students (case study). Retrieved from http://assets.pearsonschool.com/asset_mgr/current/201317/Clintondale_ casestudy.pdf

Pourhossein Gilakjani, A. (2017). A review of the literature on the integration of technology into the learning and teaching of English language skills. International Journal of English Linguistics, 7(5), 95-106. https://doi.org/10.5539/ijel.v7n5p95

Quyen, T. T. T., \& Van Loi, N. (2018). Flipped model for improving students' English speaking performance. Can Tho University Journal of Science, 54(2), 90-97. https://doi.org/10.22144/ctu.jen.2018.012

Rivera, E. (2015). Using the flipped classroom model in your library instruction course. The Reference Librarian, 56(1), 34-41. https://doi.org/10.1080/02763877.2015.977671 
Sakulprasertsri, K., \& Vibulphol, J. (2016). Effects of an English instruction using the flipped learning approach on English oral communication ability and motivation in English learning of upper secondary school students. Journal of Education Studies, 44(3), 29-45.

Sakulprasertsri, K. (2017). Flipped learning approach: engaging 21st-century learners in English classrooms. LEARN Journal: Language Education and Acquisition Research Network Journal, 10(2), 132-143.

Sanprasert, N. (2010). The application of a course management system to enhance autonomy in learning English as a foreign language. System, 38(1), 109-123. https://doi.org/10.1016/j.ystem.2009.12.010

Seilstad, B. (2012). Using tailor-made YouTube videos as a pre-teaching strategy for English language learners in Morocco: Towards a hybrid language learning course. Teaching English with Technology, 4, 3-47.

Sirakaya, D., \& Ozdemir, S. (2018). The effect of the flipped classroom model on academic achievement, self-directed learning readiness, motivation, and retention. Malaysian Online Journal of Educational Technology-MOJEST, 6(1), 76- 86.

Song, S. (2015). Cambodian teachers' responses to child-centered instructional policies: A mismatch between beliefs and practices. Teaching and Teacher Education, 50(1), 36-45. https://doi.org/10.1016/j.tate. 2015.04.004

Srihirun, W. (2017). Critical thinking with a flipped classroom. Graduate Studies Journal, 13(65), 19-28.

Strayer, J. F. (2011). Flipped classroom conference. Retrieved from https://www.skilllane.com/blog/elearning-toflipped-classroom

Strayer, J. F. (2012). How learning in an inverted classroom influences cooperation, innovation and task orientation. Learning Environments Research, 15(2), 171-193. https://doi.org/10.1007/s10984-012-9108-4

Sung, K. (2015). A case study on a flipped classroom in an EFL content course. Multimedia-Assisted Language Learning, 18(2), 159-187.

Thaichay, T. (2014). The use of a flipped classroom to enhance Thai EFL students' English accuracy and promote an active learning environment. Unpublished Master's thesis, Thammasat University, Thailand.

Unakorn, P., \& Klongkratoke, U. (2015). Effectiveness of flipped classroom to mathematics learning of grade 11 students. A Paper presented at the $21^{\text {st }} \& 22^{\text {nd }}$ International Conference on Language, Education, and Humanities \& Innovation. Retrieved from https://icsai.org/procarch/1iclehi/1iclehi-44.pdf

Villanueva, J. (2016). Flipped Classroom: An action research. A Paper presented at the 21st Annual Technology, Colleges and Community Worldwide Online Conference. Retrieved from http://hdl.handle.net/10125/40822

Zheng, M., Chu, C., Wu, Y., \& Gou, W. (2018). The mapping of on-line learning to the flipped classroom: Small private online course. Sustainability, 10, 1-14. https://doi.org/10.3390/su10030748

Zupon, K. (2017). Flipped classrooms and student achievement. Culminating Projects in Information Media, 13. Retrieved from http://repository.stcloudstate.edu/im_etds/13

\section{Copyrights}

Copyright for this article is retained by the author(s), with first publication rights granted to the journal.

This is an open-access article distributed under the terms and conditions of the Creative Commons Attribution license (http://creativecommons.org/licenses/by/4.0/). 